\title{
'Nor did ever fairies trip with such alacrity': Peregrinations since Colmcille in his Historic Footsteps
}

Johnny Rodger

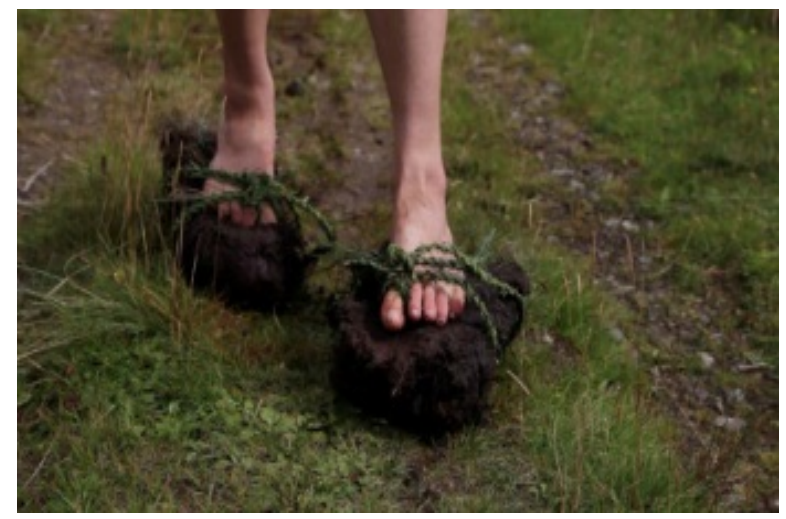

Still from Artist Jessica Ramm's video 'Walking on Peats' at Glasgow School of Art

The 'Colm Cille's Spiral' is a project involving artists, writers and scholars from across all the countries of the British Isles in which I took part in 2013. Conceived as a collaboration between practising artists and scholars in the academy, Difference Exchange, an arts agency, and King's College London, engaged the collaboration of groups from Derry, Dublin, Glasgow, Llandeilo and Lichfield, and London. The investigation and production of art and scholarly work was set to address 'the apparently remote history of a sixth century monk (St Columba/Colmcille). ${ }^{1}$ The artists and writers were supported by generous funding and the backing of several universities and arts organisations ${ }^{2}$ and a network of advisors and 
curators, in their work to endeavour to make 'connections between the extreme past and the immediate present' ${ }^{3}$ The attempt to reconnect with the past through both scholarly and artistic method, involving that is to say, academic historical research and creative reimaginings makes for an obvious immediate tension between what are ostensibly pure objective and subjective approaches to the material. As a writer and a scholar it is my thesis in this paper that it is through creative analysis of the performative aspects of cultural life in art, music, literature and dance - that these differing approaches can be brought into mutual and fruitful engagement. It was to such 'performative' ends, indeed, that the project was named Colm Cille's Spiral. For the very notion of the spiral as a circular form, returning upon itself, revolving around a centre, and involving both movement and direction, is emblematic of the methodology which structured the group dynamic. In continuous and repeated discussion, reflection, and meditation (designated as 'Convocation' by the Glasgow group), the various members of the group would come together. From the variety of positions and standpoints, personal, artistic and scholarly, the group would push on through exchange of material, practical and embodied experiential knowledge to a deeper appreciation of the significance of the figure of Colmcille and the continuing resonance of his story. It was important also, for reasons that will become clearer below, that the group should travel away from home together and spend time in a particular type of isolation as they engaged in this work.

\section{Biography}

Colmcille (or St Columba, or Calum Cille as he is known in vernacular Scottish Gaelic) was born around 521AD in North West Ireland. He was a member of the Gaelic Uí Néill dynasty, who in that era were involved in power struggles to rule that part of Ireland. In 563 as a monk he sailed from the North of Ireland to Scotland. Once there, he set up and was abbot of a monastery on the island of Iona (I Chaluim Chille). Colmcille's achievement in establishing not only the monastery of Iona, but a whole network of connected monasteries across West Britain and Ireland, has been described as 'monumental'. ${ }^{4}$ That latter description cannot however be read in its merely literal reference to the physical, the bricks and mortar grandness of his institutional achievement. As Thomas Clancy and Gilbert 
Markus write in their work on the poetry at lona: 'The monastery which he founded there would become a centre not only of prayer and devotion, but also of learning, art and -the subject of this book - poetry. ${ }^{5}$ Columba died at the lona monastery in 597.

The story of Colmcille comes to us from two source types: written document and oral tradition, and in those are contained both early and near-contemporary material and embellishments which have been added across the years. The importance of the figure Colmcille as a political, religious, spiritual, ethnic and social symbol has meant that the story has been retold with many different slants given to it down through the ages.

The earliest source is Adomnán's Life of St Columba. Adomnán was a successor to Colmcille, serving as ninth abbot of lona from 679-704. The book was written in Latin and completed during his period as abbot to inform both brother monks and outsiders of the greatness of the founder of their order on lona. Like all other tellers of this tale, Adomnán lays emphasis and shapes the story of Colmcille in a particular way, and to specific ends. Adomnán has, in fact, been criticised for being 'devoid of historical fact', ${ }^{6}$ but he drew his material both from an existing oral tradition which came from people who had actually known Colmcille, ${ }^{7}$ and from evidence in a 50-60 year earlier, but now lost, Life, written by a previous abbot called Cummene. Adomnán modelled his story on the pre-existing form of christian hagiography ${ }^{8}$, and the book sets out to demonstrate the saintliness of Colmcille through three ordered sections: respectively on his prophecies, his divine visions, and his miracles.

Alongside this classical hagiographical tradition there also exists a vernacular tradition of works written about Colmcille in Gaelic. Again this writing draws on oral tradition (as well as on available versions of Adomnán's work), although the oldest Irish text, a poem Amrae Coluimb Chille (In Praise of Columb Chille), was said to be written by Dallan Forgaill, who was a contemporary of the saint. Over the centuries and especially between the ninth and eleventh centuries $A D$ a substantial corpus of poetry about the saint was written. It comes down to us mainly through a collection made by Manus O'Donnell, who wrote an Irish vernacular 'Life of St Columba' in the sixteenth century. ${ }^{9}$

This corpus of vernacular poetry is evidence of the regard which poets have had for Colmcille through the ages, and of the inspiration which his legend has given them. (Colmcille is said to have overturned an order banishing the poets from Ireland). ${ }^{10}$ It is 
perhaps in search of a similar type of inspiration that the project Colm Cille's Spiral set out in search of the legacy of the saint for artists, writers and scholars today. Sharpe tells us however, that through history such inspiration has mutated in its forms, 'The image of the saint is a many-sided one because in different ages he was seen as representing different ideals. $^{11}$

It's no surprise then that in this current day return to the legacy of Colmcille, in the Colm Cille's Spiral project, the terminology used to describe and categorise the various different aspects of the investigation and work mixes recourse to ancient concepts like peregrination, convocation and meditation, and also leans heavily on very recent critical discourse, particularly that of Gilles Deleuze in using the idea of the 'spiral' and the 'fold' as structural themes to underpin and manage the translation of the far flung spatial and temporal aspects of the project into a coherent unity. ${ }^{12}$ Yet perhaps there are yet other, more 'traditional' concepts and critiques of settlement and organisation in space which can also give access to the principles at work in specific spatio-temporal zones. It is thus that I propose to prepare my own curving path towards the material by beginning my meditation here with an original, and perhaps somewhat unexpected analogy between the socio-spatial dynamic of the Columban early Christian world and that of the seventeenth century Baroque age.

\section{Geometry}

In Christian Norberg-Schulz's description of the Baroque Age (seventeenth century) we see how the unified, absolutist and hierarchically ordered cosmos of the Renaissance ${ }^{13}$ is fragmented and diversified. The baroque conception of the universe is ushered in with upheaval in numerous fields: the Protestant Reformation of North Europe splits Christianity apart; the rise of France as a European political power, and of England and Holland as trading nations complicates the geopolitical map; and the scientific revolutions of Copernicus and Newton see a new expansive spatial conception of the universe. From a unified world with one system and one centre, a world of proportion and the static calm rationality of the Renaissance, we move to a pluralistic world with a necessary complex set 
of relations between religions, cities, countries, stars and planets in the heavens above. As Norberg Schulz writes

The new world of the seventeenth century, therefore, may be called 'pluralistic' in so far as it offered man a choice between different alternatives, be they religious, philosophical, economic or political. ${ }^{14}$

That this baroque world of 'alternatives' can be read in the visual and spatial arts of the time constitutes the thrust of Norberg-Schulz's critical work. And this can perhaps best be read in a contrast between the iconic figure of the Renaissance Vitruvian Man --where man is placed, as a measure of all things, at the centre and focus of the perfect ideal forms, the circle and the square, with the favoured form of the baroque artist (and scientist like Newton), the ellipse, which by virtue of its two foci points is, unlike the circle or the square, dynamised and always in tension between those two points, never at rest. Again as Norberg-Schulz writes

In this infinite world movement and force are of prime importance ... Geometry, therefore is the appropriate tool for understanding the world. Whereas the geometrically ordered universe of the Renaissance was closed and static, Baroque thought makes it open and dynamic. ${ }^{15}$

\section{The text}

To what extent can such a baroque spatio-temporal model be of use to current day artists, writers and scholars as a paradigm against which to map cultural developments of another age and society ${ }^{16}$ The Colm Cille's Spiral project was set up to examine structures, realities, grounds, resonances and residues of the 'extreme past' in the form of sixth-century Colmcille or St Columba, and his legacy. In a purely formal sense, we might say, the project was organised as a type of Baroque reality with centres of activity -'knots'- distributed in multiple locations around the British Isles, and relations between them stretching like forces of tension across the map. It is however, the era of Colmcille itself that is to be compared with the Baroque era here, and hopefully some insight discovered and parallels drawn. For the case can be made that the environment into which the saint was born and grew to 
maturity was just as 'pluralistic' in Norberg Schulz's sense of 'religious, philosophical, economic or political' upheaval as was the Baroque age. Christianity spread across Ireland and mainland Britain, but it still existed -in tension - alongside a more ancient paganism. ${ }^{17}$ There was also great political upheaval with the competition by various factions for control of royal Tara, including the Uí Néill. ${ }^{18}$ In fact Colmcille himself belonged to that royal and political dynasty, and he took part in their battles and power struggles in the north of Ireland. Some traditions have it indeed, that he was forced to leave Ireland in disgrace as an outcast, or as penance for his part in causing a battle resulting in thousands of deaths; though Richard Sharpe dismisses these claims as 'inference' based on 'fanciful agendas' and points out that Colmcille remained a 'respected figure in Ireland' ${ }^{19}$

Popular legend often has it that, once in voluntary exile in Scotland, Colmcille did not only found and lead a monastic order, but he also contributed to the conversion to Christianity of the Picts -the aboriginal peoples of another linguistic and cultural make-up. ${ }^{20}$ Modern scholarship is however much more wary about making any assertions as regards Columba's role in converting any Pictish people. James Fraser reveals the sources and their historical contexts, in Bede and Adomnán, from which inferences regarding Pictish conversions are made, but remains sceptical: 'The story of Columba and the Picts is, therefore, nothing like as straightforward as conventional narratives have long held. ${ }^{21}$ The form of the Christianity that Colmcille, as a ' vibrant representative of a reformist philosophical movement bent on the reinvigoration of monasticsm ${ }^{22}$ practised in the sixth-century has also been often characterised as significant historically for its heterodoxy of observances and ritual. Again Fraser is sceptical

... its distinctiveness from other modes of thought and its occasional clashes with them, must not be confused with alienation from the wider church. ${ }^{23}$

This Christianity was thriving as an ascetic monasticism, with direct roots in North Africa and the Middle East, and thus with its rhizomic mode of organisation and propagation. Yet it was not merely an eccentric, remote and exhausted form of Christianity that was ultimately absorbed by a more vigorous Rome. The influence of those years spent isolated on little islands dotted across the vast ocean can arguably be felt in an enduring new approach to the Christian word, as seen in the beautiful texts they produced. For those 
monks, non-native speakers of Latin language from an island that was never part of the Roman Empire, were the first scribes to insert space -and indeed, punctuation - between the words in a Latin sentence thus 'In principium erat verbum', for until then all the words of a Latin script were just run together and known as scriptio continua. ${ }^{24}$ The Irish monks' texts thus constituted a textual version of the physical topologies they inhabited, where the words were isolated and discrete on the broad sea of the empty page, and the decorative 'passion' inscribed in each 'verbum' was to be taken on its own, at one time.

In terms of the Baroque model as described by Norberg-Schulz, we can see how the tensions as described above which run through society and its dealings -tensions dynastic, political, religious, cultural, theological and linguistic - dynamise it, and give it that appearance of 'fire and passion'. ${ }^{25}$ In a similar way to the Baroque era, the dynamic is evidently incorporated in their material production and their art. We see the swirling multicoloured intricate designs of their gospels -Kells, Durrow, and later Deer and Lindisfarne - where prominent motifs like the triskele, with its connected spirals on three foci which arguably make for a more infinitely restless figure than even the Baroque ellipse.

\section{The Space}

I would propose however, in my meditation, that there is a more fundamental ground upon which this society with its variegated forms and tense dynamics are sustained. This ground is an ecological one, where ecology is understood as a natural environment and the spatial and temporal relationships between the elements in that environment. The ecology of the zone inhabited by this society is a particular one, between Ireland and Scotland, European maritime, north west Atlantic, of temperate climate, archipelagic with much rough terrain on land, and travel between settlement facilitated by a fjordic coastline. As a set of spatial and temporal relations this ecology also necessitates and incorporates a type of human settlement, movement and communication. Sharpe tells us that 'Columba himself was at the centre of a network of communications, involving travel by land and sea. ${ }^{26}$ It is not to be understood as egregious that Colmcille should travel to Dalriada because 'The Hebrides were not unknown territory, for there was constant contact established long before the sixth-century between Ireland and Scotland'. ${ }^{27}$ Indeed the settlement in Ireland from which 
Colmcille had originally set out on his journey to Scotland was subsequently named after him -Doire CholmCille. It had though, originally been called Doire Calgach -literally 'the grove sacred to Calgach' - said to be named after a Scottish warrior Calgach. There was clearly then, a long history of movement back and forth across the ocean, between Scotland and Ireland, around the islands, and penetrating far into the fjordic coastlines. Charles Thomas tells us of this region that it was the sea, not the land, that unified so dispersed a colonization.' He then goes on to point out that in his Life Adomnán 'records or implies at least fifty-five separate voyages, about half of them between Ireland and Scotland. ${ }^{28}$ This ecology of movement of individuals and peoples entailed centuries of exchange and communication, as noted above, enshrined in the form of ritual, belief, language, design, art, politics and war, and as will be seen below, in song, dance, and literature too. That's not to say that 'constant contact' and 'network' of communications meant that all was literally plain sailing, for the ocean crossings could be very dangerous despite skilled seamanship (as, again, will be described below) and individual settlements could easily be cut off by rough conditions. Adomnán recounts in his Life of the saint how only brother monks could attend Colmcille's funeral because lona (at merely hundreds of yards from the shore of Mull) was cut off by bad weather for three days on end.

Nonetheless, the pilgrimage, or more properly, peregrinatio, the leaving home and going out into exile on an aesthetic spiritual quest was very much a part of the way of life for early Christian holy men. Columbanus, Patrick and Brendan are all famed for their peregrinatio. Sharpe says,

Pilgrimage outside one's native district had a strong devotional attraction in the Ireland of St Columba, and pilgrimage overseas was regarded as a sign of greater dedication and devotion than pilgrimage within Ireland. ${ }^{29}$

It is difficult to tell (pace Sharpe) whether Colmcille went on peregrinatio as a penitential act, or whether it was just as a conventional rite of passage, or routine duty as a holy man. Even if Colmcille, as based in Iona, had not gone beyond Gaeldom, he was outside Ireland itself, and there is record of him visiting various other islands (Oronsay, Skye, Eigg, and perhaps Tiree) as well as peninsulas (Ardnamurchan), before he travelled on to mainland Scotland as a missionary to the Picts. This custom of travelling out beyond the home and 
into isolated, unknown and remote zones was one which the Irish had learned under influence of the tradition of the earlier Christian desert fathers and hermits of Syria and Egypt, and it was a tradition which adapted well to the volatile native ecology where the stability required for an episcopal organisation was difficult to establish. In a sense these lonely high seas, barren hillsides, moors and bogs, through which Colmcille and other holy men travelled in search of meditation, spiritual purity and converts, were the Scots-Irish deserts.

\section{Song and Dance}

The Glasgow School of Art 'knot' of the Colmcille Spiral project - the 'Convocation' - chose to investigate that 'remote past' and its resonances by engaging in a mini-reproduction of peregrination. Some seventeen artists, scholars and technical support spent a week living and eating together, meditating alone and in small groups, and convening together in quorum, on the island of Raasay. Two exhibitions -one in Glasgow and one in Derry- and several pieces of writing -short pamphlets and blogs- have already resulted from that stay, and there might be yet more outputs to come. Raasay is, like lona, an island off the west coast of Scotland, but it may not be the obvious choice of place to engage with the Columban legacy. At the North east tip of the Inner Hebrides, this island stands diametrically opposed to lona's south-westerly, and nearer Ireland position. Raasay has no obvious immediate connection with the saint, and despite the descriptions by Adomnán of Colmcille's trips to other islands (see above) Raasay is never mentioned. Close reading of both Sharpe's appendices Adomnán's to his Life and other books on Raasay itself seem to reveal the island as settled by the sons of a cousin of Colmcille who travelled with him on his original peregrination from Derry. ${ }^{30}$ That even the most unexpected of locations on the western seaboard of Scotland can claim an albeit remote and obscure connection to the saint should not be surprising. For indeed, the main attraction of this island (much bigger than lona and far from the madding crowd of tourists now to be found there) is that it participates as fully as any other location on that coast in the archipelagic and fjordic ecology and the associated forms of human settlement and movement. 
It is what's more, a happy coincidence that the eighteenth century wing of the current Raasay House, where we stayed as a group, is the very building where James Boswell and Dr Samuel Johnson came on their own famous peregrinatio to the Highlands in 1773 , and enjoyed the hospitality of MacLeod of Raasay. The trip made by Boswell and Johnson is one of the finest modern illustrations of engagement with that enduring environmental ecology described above. The travellers, and particularly Johnson, came expecting to see 'a wilder and earlier state of things than he ever in fact encountered there'. ${ }^{31}$

Nevertheless, their respective diaries of the journey show how Boswell and Johnson's travels, like Colmcille's, were at once enhanced and hampered by meteorological, topological and maritime factors, for example Boswell writes of their attempt to leave Raasay 'It was a storm of wind and rain so we could not set out'. ${ }^{32}$ The confrontations and compromises imposed on them, and often enjoyed by them, came not only from the physical environment, but from a clash of cultures: religious and linguistic, civil and historical. There was also an uneasy sense of the way in which the physical environment thoroughly permeated through the moral and temperamental spirit and attitude of the inhabitants. Just as Colmcille's movements in that landscape are enframed in the rhythms of the monastic hours and their observances and rituals, so Johnson being rowed across to Raasay with a iorram ringing in his ears, ${ }^{33}$ notes that the eighteenth century inhabitants have their own special rhythms

They accompany in the Highlands every action which can be done in equal time with an appropriate strain, which has, they say, not much meaning, but its effects are regularity and cheerfulness. The ancient procleusmatick song, by which the rower of gallies were animated, may be supposed to have been of this kind. ${ }^{34}$

Examination of the Journals could arguably lead the reader to the conclusion that of all the places they visited on the western seaboard, Raasay offered them the most lively and enjoyable of experiences. After an evening of dance and music there Boswell wrote 'Dr Johnson was so delighted with the scene, that he said, 'I know not how we shall get away'. ${ }^{35}$ And Johnson himself writes of the dancing which took place in the hall there (nowadays a ping-pong room) 'Nor did ever fairies trip with such alacrity'. ${ }^{36}$ At a later date in their trip Boswell describes a dance in which he takes part, and which incorporates in its rhythms, 
sounds, and movements symbols of life on land and sea in its political, civil and historical realities and represents them in time and space:

In the evening the company danced as usual. We performed, with much activity, a dance which, I suppose, the emigration from Sky has occasioned. They call it 'America'. Each of the couples, after the common involutions and evolutions, successively whirls round in a circle, till all are in motion; and the dance seems intended to shew how emigration catches, till a whole neighbourhood is set afloat. Mrs MacKinnon told me that last year when a ship sailed from Portree to America, the people on shore were almost distracted when they saw their relations go off; they lay down on the ground, tumbled and tore the grass with their teeth. ${ }^{37}$

It is clear that for these Highlanders, in the post 1745 collapse of their society, NorbergSchulz's observation on the Baroque age that 'In this infinite world movement and force are of prime relevance' has its own special analogous applicability. But unlike the Baroque and the Columban age, for these illiterate peasants it is not geometry and design, but dance, music and song that is the 'appropriate tool' for both understanding and coming to terms with their 'pluralistic' eighteenth century world.

\section{Poetry}

Of course the eighteenth century brought its own particular social, political and religious upheaval to Highland life, but there are enduring aspects to the ecological dynamic of the politics of this place, and to the modes of inhabiting this environment, which are perhaps most apparent when we read the literature written by people here across the ages. There is for example a noticeable quality of closeness to nature and particularly an affinity and sympathy for animals, which is seen at once in the descriptions of Columba's treatment and understanding of the horse just before his death in Adomnán's Life. This appears again in eighteenth century poet Donnchadh Ban Mac an-t-Saoir's description of deer in his great poem 'Moladh Beinn Dobhrainn' (see for example in MacDiarmid's translation, 'Every hind going at ease/Slim, neat, a sight to please,/With her fawns by her knees,/Or all with white 
tails on the breeze/Filing up through the passes.') ${ }^{38}$ Clancy and Markus are sceptical about the notion of an inherent closeness to nature in 'Celtic sprituality'. They see the writers in the tradition of monks writing 'nature' poetry as a phenomenon coming from literary men living in the great cultivated monastic towns, 'like the urban nature lovers of the late twentieth century'. They go on to say that 'a real hermit, living in a damp stone or wooden cell, fasting in hot and cold weather to subdue the flesh, terrified of thunder and lightning, as the author of Noli Pater evidently was, is not the author of these 'nature poems'. ${ }^{39}$

Nonetheless, the continuity in concern of themes and modes of presentation is arguably seen most strongly in an examination of treatments of that most important and vital constant in this territory -the sea journey, as noted in the citation from Charles Thomas above. One of the fifty-five journeys Adomnán describes in most detail is that of Cormac, sailing, as Colmcille had done, from the North of Ireland to the west of Scotland, and coming into a storm:

quaedem quippe usque in id temporis invisae mare obtegentes, occurrerant tetrae et infestae nimis bestiolae quae horribili impetus carinam et latera, puppimque et proram ita forti feriebant percussura ut pelliceum tectum navis penetrales putarentur penetrare posse

...the whole sea was covered with deadly loathsome little creatures. They struck with horrible force against the keel, against the sides of the boat, against the stern and the prow, and the pressure of them was so great that it was thought they would pierce the skin covering of the boat. ${ }^{40}$

If we place this text alongside an excerpt from a text written some 1100 years later we see astonishing similarities. The 'Birlinn Chlann Raghnaill' ('The Longship of Clanranald') was published in Gaelic in the late eighteenth century by Alasdair MacMhaighstir Alasdair, who came from Moidart, a peninsula just north of Ardnamurchan on the Scottish mainland. The poet, who fought in the 1745 Jacobite Rising and was Charles Edward Stuart's Gaelic tutor, is seen alongside Donnchadh Ban as one of the great writers of modern eighteenth century Gaelic poetry. ${ }^{41}$ The 'Birlinn' describes a sea journey from South Uist in the Outer Hebrides to Carrickfergus in the north east of Ireland. Again that is a journey which covers much of 
territory crossed by Colmcille and his contemporaries, and it is one done in the opposite direction to Cormac's.

An fhairg' uile 's i 'na brochan

Strioplach, ruaimleach

Le fuil 's le gaorr nam biast lorcach

'S droch dhath ruadh oirr'

Na biastan adharcach, iongnach,

Pliutach, lorcach,

Làncheann 'siad 'nam beòil gu 'n giallaibh,

'S an craos fosgailt.

An àibheis uile làn bhòcan

Air an cràgadh ${ }^{42}$

The whole sea was a foul porridge

Full of red scum

With the blood and ordure of the beasts

Ruddy, glum,

While screaming with their gill-less mouths,

Their jaws agape,

Even the air's abyss was full of fiends

That had no shape,

With the paws and tails of great monsters 


\section{Gruesome to hear ${ }^{43}$}

There are, of course, obvious differences between the texts. One is written in eighteenth century Gaelic vernacular, the other in seventh century Church Latin. One is written in the lyrical form of the long poem, the other is part of a prose hagiography -though both are 'traditional' forms with many precedents in their respective literary cultures. ${ }^{44}$ As regards the content, one journey, Derry-lona, is much shorter than the other, and made by holy men for religious purposes. The other gives us no clue as to the business for which Gaels from the Outer Hebrides are sailing to the North of Ireland. The earlier sailing is made in a primitive vessel probably constructed of hide and wicker, ${ }^{45}$ the latter one is a timber sailing boat.

There are also several striking similarities in the texts. Both make great play of seamanship and the centrality of journeying on the sea to their way of life. They both have dramatic passages detailing a storm at sea and its effect on the vessel and its passengers. Clancy and Markus note in their study of the medieval poetry in the lona tradition that the image is a common one, which may have its origin in the Gospel story of Jesus saving his disciples in a stormy sea crossing. ${ }^{46}$ They go on to say:

The vulnerability of a sailor in a frail boat on the open sea is an eloquent symbol of the Christian life and Irish writers made full use of it. But the sea voyage was clearly far more than a literary device. Countless Irish Christians, seeking to follow Christ more closely through asceticism and abandonment of earthly security, were to seek him as wanderers and exiles. Such exile, for the people of these islands, would often mean a quite literal entrusting of one's life to the waves and to the mercy of God. ${ }^{47}$

Both excerpts above also show a delight in verbal virtuosity in the description of the storm at sea (see lines in the 'Birlinn' consisting merely of lists of adjectives). Here we see the Gaelic tradition of praise poetry, (in which MacMhaighstir Alasdair was well practised ${ }^{48}$, and of which we see the earliest Gaelic example in the Amrae Choluimb Chille ${ }^{49}$ ) with its short lines and its lists of glorious titles, which is very similar to the medieval form of the Christian litany, where the divine majesty is 'approached with a mixture of trust and awe'. ${ }^{50}$ This listing of qualities of the object in hand encourages the reader to linger and savour each 
individual word on their own, just as do the Insular gospels, isolating individual words via their startlingly complex and colourful designs.

In neither boat are there any women -Colmcille himself had made his legendary crossing from Derry to Scotland with twelve others -all men. It was deemed bad luck to have women on board. A Freudian interpretation of that absence of women could perhaps make a rich commentary on the subsequent appearance in both texts of aggressive, ugly and bloody monsters, churned up to terrorise the men, from the depths of a sea 'churning and lashing itself in maniacal states' ${ }^{51}$ Perhaps recourse to Jung and his archetypes and religious and spiritual avatars would, however, bring us nearer to an understanding of a possible deeper symbolic significance here. A modern day Gaelic proverb attributed to Colmcille is usually interpreted as an explanation for the lack of cattle on the monastic lands of lona; Far am bi bo bidh bean, 's far am bi bean bidh mallachd. ${ }^{52}$

(Where there is a cow there is a woman, and where there is a woman there is trouble.)

Hence cows would attract women (ie dairy maids) and as women should be kept away from the monks for reasons of spiritual purity, then no cows should be allowed on the island either. Yet things might not be so straightforward as they seem there: the cow of the proverb could in fact be interpreted as a pre-christian symbol of the mother goddess, and the matriarchal cult. John Maclnnes writes of several sites he knows of in Gaeldom today (Scottish and Irish) which are named after 'mythological cows or cow goddesses' and which signal these places as of 'importance in pagan times as a centre of religious activity. ${ }^{53}$ In that case the stricture regarding cows and an evident bigotry and superstition against women can be understood as an enduring resonance from the era of Christian efforts to supersede and subsequently suppress paganism in these lands. Yet would the adoption of such a stance in interpreting that folk material not be to project and impose the needs and truths of our own age, as regards the historical oppression of women, on the material? Clancy and Markus note that Colmcille himself in his attempts to find peace for prayer and meditation was already 'frustrated' even in remote lona by crowds of visiting pilgrims, and the building of the vallum or wall around the wooden monastery enclosure in those days was meant to keep not just women, but 'laymen' and all other non-clergy out. ${ }^{54}$ The picture is further complicated by Clancy and Markus's reading of a connection between the 
protection afforded to women by both Adomnán (in his laws protecting the vulnerable from harm in warfare) and Colmcille (several passages in the Life recount of a "kind of manifesto for the social programme of his monastery'), and its cult of devotion to the Blessed Virgin as seen not only depicted in their holy books, but also on the sculptures still extant on lona. ${ }^{55}$

The intention here is thus not to demonstrate a cultural stasis, an absolute identity of the creative forms of life and of the scope for expression (here in literature) across 1200 years. But nonetheless environmental factors -meteorological, topological, geological and maritime contexts- endure, and a grounding of human poetic, spiritual, practical and political endeavours and their traces and effects have a long history of engagement with that environment. If Colm Cille's Spiral is to uncover 'connections' to the 'remote past' then is that not to usher the new in together with the old? An authentic way to set out on such an endeavour might be to recreate the monastic peregrination to an isolated location with an active crew of ten women and eight men.

\section{The figure}

After such analysis however, the question remains about whether we are any closer to understanding the actual legacy of the sixth century monk called Colmcille. When Clancy and Markus say of Colmcille that 'by the time of his death he already had an incomparable reputation for just these virtues', they mean by that latter word 'wisdom, learning and holiness'. They also say his 'achievement was monumental', yet my 'ecological' analysis here attempts to account directly for the cultural developments as environmental effects of factors social, political, topographical and meteorological. Several deeply troubling questions arise here. Are we not, by adopting a critical stance similar to Norberg-Schulz, simply falling foul of Woelfflin's criticism of 'summarising long periods of time under concepts of a very general kind'? How is it possible with a critical approach to get at the personal and spiritual legacy of one person from a very long time ago? And, is it too naïve to ask if there is no place for the subject in such an objective account: is 'man', as Woelfflin says, to be 'regarded purely as a form-experiencing creature, enjoying, tiring, demanding fresh stimuli, not as a real and vital being ${ }^{56}$ ? Perhaps it is only by changing our very 
language, by imagining our way, via art and poetry that we can say something that otherwise would not be possible here?

It is just such a dilemma as that faced by Thomas Carlyle in his attempts to uncover certain kinds of truths. As a young writer he had been working as a critic, but in 1829 with the writing of the essay 'Signs of the Times' he reached a crisis point, where he realised that this critical prose only touches on externalities, and that in his nineteenth century industrial Age, 'Men are grown mechanical in head and heart, as well as in hand. ${ }^{57}$ Carlyle sets up a contrast between the 'mechanical' approach, and the 'dynamic' approach, which latter takes account of the inner life, the spirit. In outline of this dilemma he specifically opposes the critical and the religious/spiritual conception of life:

To the eye of a Smith, a Hume or a Constant, all is well that works quietly. An order of Ignatius Loyola, a Presbyterianism of John Knox, a Wickliffe, or a Henry the Eighth are simply so many mechanical phenomena, caused or causing. ${ }^{58}$

Carlyle is nonetheless aware in his setting up of the antagonistic dualism between the 'dynamic' and the 'mechanical' principles, that 'undue cultivation' of the dynamic would lead to 'superstition and fanaticism' ${ }^{59}$. In 'Signs of the Times' he is, however, unable to do more than preach a critical discourse to us about the necessity for a greater development of the dynamic principle. It is not until a few years later, after much work and study that Carlyle finds the tool he needed to act upon the perceived necessity outlined in that essay. He develops what he calls his 'Babylonish Dialect', a poetic style through which he engages his own imagination to bring a character -in the case of Sartor Resartus- or a whole historical period -in the French Revolution- to life. He draws this poetic style out from his own personal resources: like the poetry of MacMhaighstir Alasdair it has cosmic scope, is rhapsodic and affected, it makes use of satire, invective and irony, and thus is an answer in itself to the plodding Mechanistic problem. To some extent it can be shown that he developed this style through his readings of German writers like Goethe, Jean Paul and Novalis ( although there are of course other very important influences, such as his strict Presbyterian background, and Biblical influences). ${ }^{60}$ He puts his own personal formation at stake in every sentence with this style. He describes its idiosyncrasies himself in an oblique fashion in the French Revolution 
For ours is a most fictile world; and man is the most fingent plastic of creatures. A world not fixable: not fathomable! An unfathomable Somewhat, which is Not we; which we can work with, and live amidst, --and model, miraculously in our miraculous Being, and name World. -But if the very Rocks and Rivers (as Metaphysics teaches) are, in strict language, made by those outward Senses of ours, how much more, by the Inward Sense, are all Phenomena of the spiritual kind: Dignities, Authorities, Holies, Unholies! Which inward Sense, moreover, is not permanent like the outward ones, but forever growing and changing. ${ }^{61}$

It is by such a staking of the personal, creative vision that the artist is able to bring another subject to life, and that is what makes their work different from the purely scholarly work as an external understanding of the 'phenomena caused or causing'. This is indeed the route by which artists and writers can bring such a great ancient and personal legacy to light, by immersing themselves in those environmental factors, those 'concepts of a very general kind', then speaking as and from themselves alone.

Another exemplary work here is Flaubert's The Temptation of St Antony, which is of special interest because of the relation and influence of its subject as an early Christian desert father on Colmcille, and also in regard to its relation to Anathasius' fourth century hagiography of St Antony, which as related above, was one of the models chosen for Adomnán's Life. Rather than a hagiography of St Anthony, however, Flaubert's is a work of creative literature which uses the basic elements of St Anthony's biography as a framework upon which to hang a poetic work of fiction which explores extreme states of consciousness. Beyond the special significance for us of that content, however, it is the style Flaubert evolves in the writing of this book that is of most interest here. Like Carlyle, Flaubert developed his own poetic style, and he spent over a quarter of a century working on a sequence of versions of the piece. He brings a new vividness to his depiction of the saint's life as a dramatic prose poem, a phantasmagoria with an extravagant and fantastic series of images of the mystic saint's hermetic existence in the desert. It is merely coincidental to our naming of our project - but a very interesting coincidence nonetheless - that Flaubert originally called his work 'The Spiral'. In her introduction to the Penguin edition, Kitty Mrosovsky recounts how Flaubert developed his writing style from his readings of Spinoza, the German Idealists (as did Carlyle), Oriental pantheists, and from the 'brilliant 
hallucinations' which he himself suffered as an epileptic. She goes on to describe his work thus

Saint Antony, coloured as it is by Flaubert's hallucinations, can be seen both as an esoteric personal record and as an experiment teased out over a quarter century, to perfect an 'infinite spiral' of images. ${ }^{62}$

In this one work then Flaubert attempts, by calling, like Carlyle, on his own personal imaginative resources, to reach truths beyond the historical, the finite, and the rational -in one early version of the work the Seven Deadly Sins which come to tempt Antony are supplemented by an eighth -'Logic'. At a later point in her 'Introduction' however, in a discussion which seems to parallel Carlyle's warnings about the danger of 'fanaticism' and the movement to a subjective extreme at the opposite pole from Woelfflin's critique of the view of the subject as merely a 'form-experiencing' automaton, Mrosovsky then assesses Sartre's critique of Flaubert. Sartre seems to see in Flaubert's re-imagining of the St Antony legend too great an imposition of his own person, such that it is an autistic work, an elaborately nihilistic assuaging of his own impotence (his epilepsy being one symptom) on the historic material. ${ }^{63}$

\section{Conclusion and Coda}

There is no settled critical agreement on the value of Flaubert's St Antony in comparison with a more realist work like Madame Bovary, and all ultimately depends on one's view of the relative value of objective and subjective truths. In a significant way this was also the crux for much of the interdisciplinary discussion in the Colm Cille's Spiral group. For academics and scholars in the group were intrigued - and often baffled - both by the artists' use of the word and concept 'practice' to describe their professional work, and how that work often seemed to place the artists themselves, their person, and often even their body, at the centre of the investigation of a distinct historical phenomenon. As seen in the work of Carlyle and Flaubert however, one of the vital functions of art is its performance of an ongoing negotiation, and repair of the divide, between the object in history and subject which experiences it. In that sense is not the production of art itself a most humane and ethical operation, as a seeking to balance emotional needs and imaginative creations with 
historical facts and conceptual necessity? Hence writers and artists are able to construct an authentic relation to a fragmented and buried distant past by staging those vestigial cultural forms that are bequeathed to us in their own way, like Carlyle's French Revolution, or even more so, like Flaubert's St Anthony. And the connection made through their artistic work is to a 'vital being' rather than to a merely historical 'form-experiencing creature'. ${ }^{64}$

Thus, for example, one artist in the Glasgow group of Colm Cille's Spiral, Jessica Ramm, put herself in Colmcille's shoes in a very literal way which could lend the viewer of the film she exhibited some new understandings of the existential condition of the peregrinatio in this particular ecology. One legend has it that having promised he would not set foot on Irish soil again, Colmcille, on his actual return to visit that island, strapped Scottish peats to the soles of his feet, so that he did not walk into dishonesty. ${ }^{65}$ Jessica (see a still from her film at the head of the article) cut peats, strapped them to her feet and filmed herself walking along. She later wrote of this work that in general the walk of an exile is 'awkward and repetitive' but that an exile 'must make audacious arrangements for return'. Of Colmcille, she noted after her walk, that his feet must have been 'heavy with the weight of penance. ${ }^{66}$

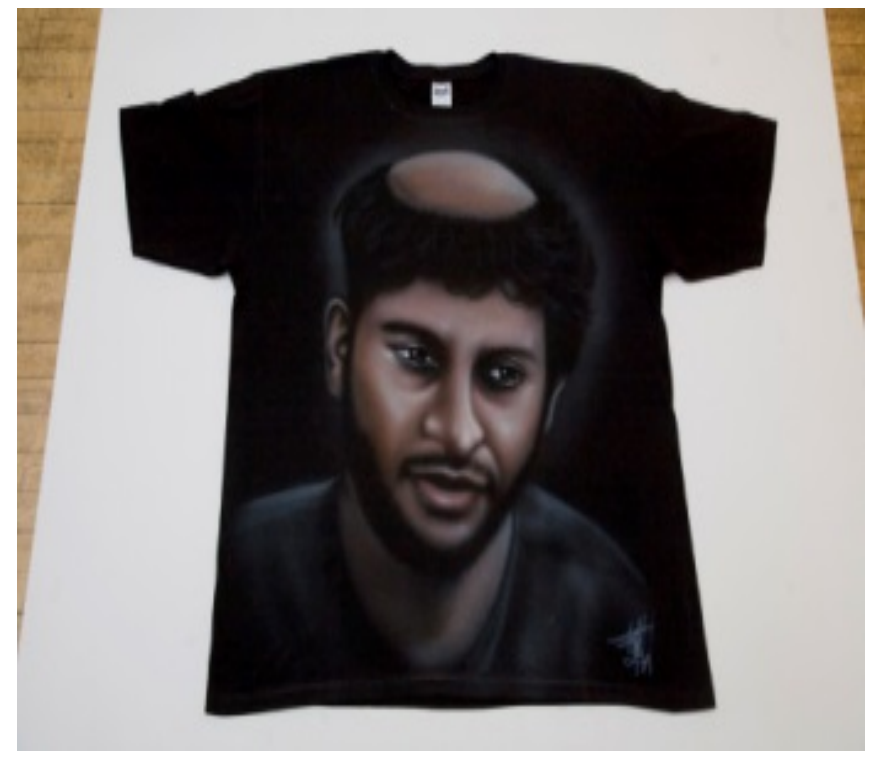

As one might suspect, however, there was not always consensus amongst the group of artists and scholars. Artist Hardeep Pandhal created a dialogue of his deep sense of ill-ease with some aspects of the project by exhibiting a selection of objects on a 'coffin-esque' plinth. Among the objects were a t-shirt with the incongruous image of himself printed on it as a British Asian with the tonsure as of an early Christian monk. He also exhibited there a 
decorated and defaced copy of Erasmus's 'In Praise of Folly' alongside a copy of what he cynically called the 'mandatory' reading of the project (also decorated and defaced), namely Adomnán's hagiography. This ironical stance was then, clearly modelled on Erasmus, a catholic priest, who, in the work displayed as an evident alternative to Adomnán's hagiography, set himself up as one wholly absorbed and belonging to the tradition or the group, while at the same time critiquing it for its superstitions and its stupidities. ${ }^{67}$ The stance allowed Hardeep to highlight issues about the 'ethos' and 'intentions' of the whole project. His mode of raising questions about the type of 'ritual' behaviour by artists and academics in their 'conjecture' about the past was to make a full insistent personal identification with the ultimate profanity of historical research - to become his object. ${ }^{68}$ We noted Carlyle, above, warning about the dangers of 'superstition and fanaticism' in the overly spirited or subjective approach. But does not Hardeep indeed draw attention to what he perceives as dangerous 'superstition' in some aspects of the group's approach (- as did Erasmus in 'In Praise of Folly' -) in his case by posing his own 'fanaticism' alongside it?

Another of the artists, Caroline Dear, noted that the Gaelic name for Iona is 'I' -as in 'I Cholm Chille'. That is undoubtedly an objective fact, yet it struck her also that the word ' $\mathrm{l}$ ' is one which, in English at any rate, many academics are constantly striving to efface from their objective, scholarly work. Caroline also knew of the legend that since he came to lona, Colmcille had never once had anything other than Scottish soil under his feet -not even when he returned to Ireland . So she gathered some peat, made a thick solution in rainwater, and smeared, in giant size, the word 'I' onto the gallery wall. In effect, this was her own dirty Insular protest, for here she was, a woman from Skye, making a work on the mainland in Glasgow. That solitary word, isolated there on the wall is also of course the first letter of the Gospel of St John, and as such was inscribed and decorated after their own fashion by the monks of Iona in the so-called Book of Kells. Caroline's art work is entitled 'The Nature of I'. I made it from the very earth upon which Colmcille walked, Caroline said factually. Yet that ' $l$ ' could not be written in scholarly discourse, could it now? 


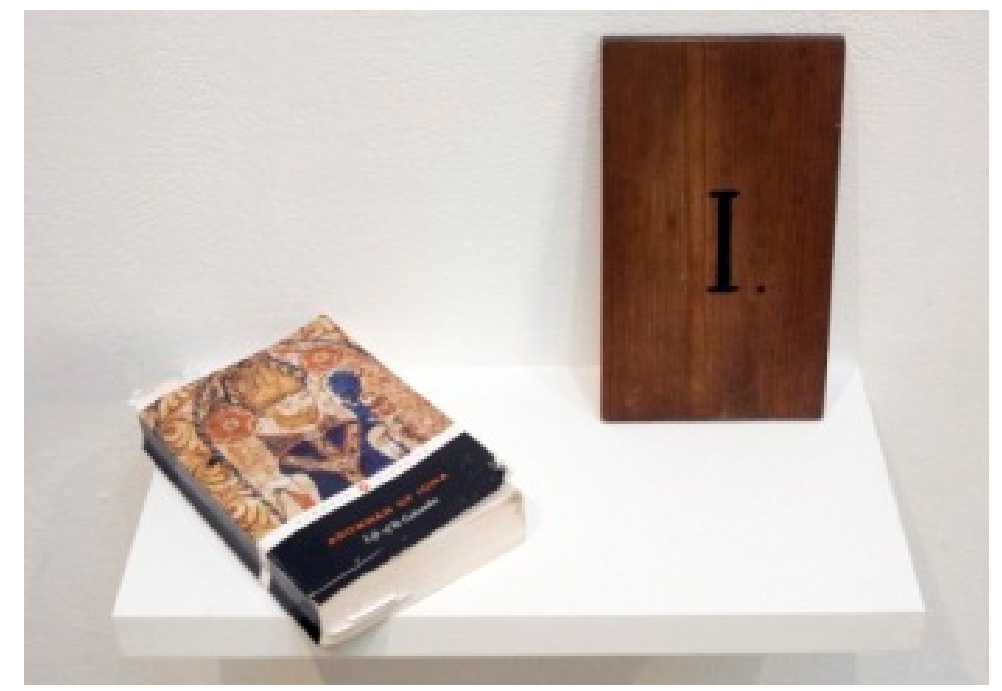

Artist Caroline Dear's Adomnán of lona and a found object displayed at Glasgow School of Art

\footnotetext{
${ }^{1}$ John Hartley, http://www.colmcillespiral.net/completing-the-fold/ last viewed 17/12/13

${ }^{2}$ Institutions providing backing were : King's College London, Glasgow School of Art, University of Glasgow, Trinity College Dublin, Centre for Contemporary Art, Glasgow, Derry/Londonderry 2013, Atlas Arts, Difference Exchange, Creative Scotland and Arts Council of Wales.

${ }^{3}$ Ibid.

${ }^{4}$ Thomas Clancy \& Gilbert Markus (1995), lona: The Earliest Poetry of a Celtic Monastery, Edinburgh University Press. p11.

${ }^{5}$ Ibid.

${ }^{6}$ E. Mairi MacArthur (1995), Columba's Island: Iona from past to present, EUP, Edinburgh p11

${ }^{7}$ Adomnán of Iona, Life of Saint Columba, Richard Sharpe (trans. \& ed.), Penguin, London, 1995. p59.

${ }^{8}$ Sharpe, in Adomnán pp57-8, shows that Adomnán's Life of St Columba is written in the Christian hagiographic style which began with the fourth century Life of St Anthony by Athanasius, and translated to Latin by Evagrius, and Life of St Martin, by Sulpicius Severus.

${ }^{9}$ Adomnán pp89-90.

${ }^{10}$ Adomnán pp89. Sharpe also says on $\mathrm{P} 90$ 'there are two narrative themes underlying this material: first that Columba was in a special sense the patron saint of the poets, and, second, that he was more than anything else an exile from his Irish homeland.'

${ }^{11}$ Adomnán p87.

${ }^{12}$ Hartley

${ }^{13}$ That is the Renaissance view of one world at the centre of the one solar system, created by God for his one favoured creature, and one European religion centred on one powerful city Rome.

${ }^{14}$ Christian Norberg-Schulz, Baroque Architecture, Faber and Faber, London, 1986. p7

${ }^{15}$ Ibid p8

${ }^{16}$ Not all theorists of the baroque concur with Norberg-Schulz's understandings of the sources of baroque art, or with his socio-spatial, or cultural historical approach. For example Woelfflin in a chapter 'The Causes of the Change in Style' writes 'This psychological approach has also been used to explain the new formal conception that comes with the baroque. According to this point of view the formal style is the expression of its age; it is
} 
not a new approach, but one which has never been systematically founded. The technical side of the profession has always opposed it, sometimes with reason, for the so-called 'kultur-historisch' introductions in textbooks contain a good deal that is ridiculous, summarising long periods of time under concepts of a very general kind which in turn are made out to account for the conditions of public, private, intellectual and spiritual life.' Heinrich Woelfflin, Renaissance and Baroque, Collins, 1964, p76.

${ }^{17}$ Ruth and Vincent Megaw Celtic Art, Thames \& Hudson, London, 2001. pp244-5; Adomnán p2, Sharpe says, 'Indeed it is probable that at the time of Columba's death many of the Irish people and most of the inhabitants of Scotland were still pagan.'

${ }^{18}$ Ibid.

${ }^{19}$ Adomnán P.15

${ }^{20}$ See for example http://en.wikipedia.org/wiki/Columba last viewed 22/12/14

${ }^{21}$ James Fraser (2009), From Caledonia to Pictland, Scotland to 795 (New Edinburgh History of Scotland), Edinburgh University Press, p105.

22 Ibid. p103.

${ }^{23}$ Ibid. p80

${ }^{24}$ Paul Saenger (2000), Space Between Words: The Origins of Silent Reading, Stanford UP

${ }^{25}$ Ruth \& Vincent Megaw, Celtic Art, Thames and Hudson, London 1989, p247.

${ }^{26}$ Adomnán p.22

${ }^{27}$ Ibid. p.16

${ }^{28}$ Charles Thomas (1986), Celtic Britain, Thames and Hudson, p.91.

${ }^{29}$ Ibid. p.12

${ }^{30}$ In the appendix to Adomnán's Life p354, the document lists a cousin of Columba's as the mother of the men of Moccu Cein. In p79 of the of John Maclnnes, Duthchas Nan Gaidheal, Birlinn, Edinburgh, 2006, in the essay 'Gleanings from the Raasay Tradition' Maclnnes cites Dr C O Baoill's essay 'Innis Moccu Chein', Scottish Gaelic Studies 12 (1976), 267-270, where O Baoill claims that Raasay is Innis Moccu Chein' -or the island of the Moccu Cein.

${ }^{31}$ Peter Levi (ed.) p15, Samuel Johnson and James Boswell: A Journey to the West Highlands and Islands of Scotland \& The Journal of the Tour to the Hebrides, Penguin, 1984

32 Ibid. p259

33 'iorram' is the Gaelic term for a boat song or a rowing song.

${ }^{34}$ Levi p77

35 Ibid. p253

${ }^{36}$ Ibid. p74

${ }^{37}$ Ibid. p327

${ }^{38}$ MacDiarmid Complete Poems Vol1, Penguin, 1978, p589.

${ }^{39}$ Clancy p90.

${ }^{40}$ from Vita Sancti Columbae, Adomnán, $\left(8^{\text {th }}\right.$ C) Lib. II, Cap, 43. With Sharpe's translation in Adomnán p.197.

\footnotetext{
${ }^{41}$ MacMhaighstir Alasdair, as a university educated, literate poet, is also said to have been a great influence on the illiterate Donnchadh Ban. The contemporaries fought on opposite sides in the 1745 Jacobite Rising.

${ }^{42}$ Alasdair MacMhaighstir Alasdair: Selected Poems, Derick S Thomson (ed.), Scottish Gaelic Texts Society, 1996, p151.

${ }^{43}$ MacDiarmid p529

${ }^{44}$ Derek S Thomson, editor of MacMhaighstir Alasdair, shows on p136 that the latter's text for the 'Birlinn Chlann Raghnuill' has centuries old avatars among the ancient Gaelic poetry of Scotland and Ireland, which include passages in the fifteenth century Gaelic prose narrative work Cath Finntragha. Thomson also says of MacMhaighstir Alasdair that he may have encountered the forms in his reading of classical literature also.

${ }^{45}$ See Adomnán cited above at note 40 , 'pierce the skin covering of the boat'.

${ }^{46}$ Mark 6, 47-52; John 6, 19-21
} 
${ }^{47}$ Clancy p75

${ }^{48}$ See various poems in Alasdair MacMhaighstir Alasdair, including 'Moladh Moraig' and 'Moladh Ughdair don t-seann Chanan Ghaidhlig'.

${ }^{49}$ See Clancy pp96-128.

${ }^{50}$ Ibid. p74

${ }^{51}$ MacDiarmid

${ }^{52}$ F Marian MacNeill (1920), lona: a History of the Island, Blackie and Son, p.92. ; Alexander Nicolson (ed.) (1996) Gaelic Proverbs, Birlinn (first published 1881) p.198.

${ }^{53}$ Maclnnes p79

${ }^{54}$ Clancy p20.

55 Ibid. pp. 33-4

${ }^{56}$ Woelfflin, p74.

${ }^{57}$ Thomas Carlyle, 'Signs of the Times' in Miscellaneous Essays, Chapman and Hall, London (1839), p.235.

${ }^{58}$ Ibid. p246.

${ }^{59}$ Ibid. p244-5

${ }^{60}$ See Rodger, J, 'From Slogan to Clan: Scotto-Germanic Romantic relations', Scottish Cultural Review of Language and Literature, Vol 18, pp189-212, 2012

${ }^{61}$ Thomas Carlyle (1837). The French Revolution. A History. 3 vols. London: Chapman Hall. Vol 1, p.6.

${ }^{62}$ Gustave Flaubert The Temptation of St Antony, (Trans. And Introduction Kitty Mrosovsky, 1980), Penguin. 'Introduction' p.12

63 Ibid. pp32-3.

${ }^{64}$ Woelfflin ibid.

${ }^{65}$ See Lucy Menzies (1920), Saint Columba of Iona: A Study of His Life, His Times, \& His Influence, Dent, London. On p. 135 Menzies writes that Manus O'Donnell 'mentions also "a sod of the earth of Alba under his feet", so that he might not tread the soil of Erin'.

${ }^{66}$ http://creativefutureshq.com/projects/colm-cilles-convocation/ last viewed 29/1/2014

67 'In Praise of Folly' was first published in 1511 in Latin as Stultitiae Laus by Desiderius Erasmus of Rotterdam. (Usually known simply as Erasmus) It contains a satirical critique of superstitions and practices current in Christianity. Erasmus was a priest, and although he was a contemporary of Luther, and like the latter, a critic of the Catholic Church, he never joined with the reformers in their split from Rome.

${ }^{68} \mathrm{http}: / /$ creativefutureshq/projects/colm-cilles-convocation/

${ }^{69}$ Ibid. 